\title{
Immobilization of $\beta$-galactosidase from Kluyveromyces lactis onto a polysiloxane-polyvinyl alcohol magnetic (MPOS-PVA) composite for lactose hydrolysis
}

\author{
David F.M. Neri ${ }^{\mathrm{a}, \mathrm{b}, *}$, Victor M. Balcão ${ }^{\mathrm{a}, \mathrm{c}}$, Maria G. Carneiro-da-Cunha ${ }^{\mathrm{b}}$, Luiz B. Carvalho Jr. ${ }^{\mathrm{b}}$, José A. Teixeira ${ }^{\mathrm{a}}$ \\ ${ }^{a}$ IBB-Institute for Biotechnology and Bioengineering, Centre of Biological Engineering, Universidade do Minho, Campus de Gualtar, P-4710-057 Braga, Portugal \\ ${ }^{\mathrm{b}}$ Departamento de Bioquímica and Laboratório de Imunopatologia Keizo Asami, Universidade Federal de Pernambuco, Brazil

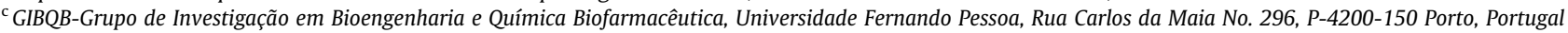

\section{A R T I C L E I N F O}

\section{Article history:}

Received 11 January 2008

Received in revised form 19 May 2008

Accepted 20 May 2008

Available online 24 May 2008

\section{Keywords:}

$\beta$-Galactosidase

Kluyveromyces lactis

Covalent immobilization

Polysiloxane

Polyvinyl alcohol

Magnetic support

\begin{abstract}
A B S T R A C T
$\beta$-Galactosidase from Kluyveromyces lactis was covalently immobilized onto a mPOS-PVA, using glutaraldehyde as activating agent and its properties were evaluated. The enzymatic water insoluble derivative displayed the same optimum $\mathrm{pH}(6.5)$ and optimum temperature $\left(50{ }^{\circ} \mathrm{C}\right)$ of the soluble enzyme. The apparent $K_{\mathrm{m}}^{\mathrm{app}}$ and activation energy for both soluble and immobilized enzyme derivative were found to be not significantly different. The mPOS-PVA $\beta$-galactosidase preparation presented a higher operational and thermal stability than the soluble enzyme. This immobilized $\beta$-galactosidase also was effective in hydrolyzing lactose from milk. Hence, one can conclude that mPOS-PVA is an attractive and efficient support for $\beta$-galactosidase immobilization.
\end{abstract}

(c) 2008 Elsevier B.V. All rights reserved.

\section{Introduction}

In the last few years, immobilized enzymes have been extensively studied for its use in food applications [1]. $\beta$-Galactosidase (EC 3.2.1.23), commonly known as lactase, has received a particular interest as it can be used to produce an isomolecular mixture of glucose and galactose [2]. The major biotechnological application of this enzyme lies in the production of low-lactose milk (and its derived dairy products) for consumption by lactose-intolerant persons [3]. Additionally, galactooligosaccharides can also be formed by transgalactosylation.

Lactase can be found in microorganisms as well as in plant and animal tissues. However, the use of both native and soluble enzyme is limited by economic considerations [4,5]. Such drawback may be overcome by using more stable and reusable immobilized enzyme biocatalysts that can be easily removed from the reaction medium, thus lowering the costs involved [6,7]. Immobilization of $\beta$-galactosidase from Kluyveromyces lactis has been performed by

\footnotetext{
* Corresponding author. Address: IBB-Institute for Biotechnology and Bioengineering, Centre of Biological Engineering, Universidade do Minho, Campus de Gualtar, P-4710-057 Braga, Portugal. Tel.: +351 253604406; fax: +351 253678986.

E-mail addresses: davidfmneri@yahoo.com.br (D.F.M. Neri), vbalcao@ufp.pt (V.M. Balcão), mgcc@ufpe.br (M.G. Carneiro-da-Cunha), lbcj@hotlink.com.br (L.B. Carvalho Jr), jateixeira@deb.uminho.pt (J.A. Teixeira).
}

covalently binding it on thiopropyl-agarose [8] and cellulose-gelatin [9] supports. Immobilized enzyme derivatives have also been reported for the lactase from Kluyveromyces fragilis [10], Thermus sp. [11,12], Escherichia coli [13] and Aspergillus oryzae [4,14]. The use of magnetic particles as support for enzyme immobilization presents the following advantages: higher specific surface area obtained for the binding of a larger amount of enzyme, on a mass basis, lower mass transfer resistance and less fouling, and selective separation of immobilized enzyme particles from a reaction mixture by simply applying a magnetic field around the reactor [15]. In this research effort we describe a simple and inexpensive procedure to synthesize a magnetic enzyme derivative of $\beta$-galactosidase from $K$. lactis. Firstly, beads of a semi-interpenetrated network of polyvinyl alcohol (PVA) and polysiloxane (POS) is produced by sol-gel technique. Secondly, these beads (POS-PVA) are converted to powder and magnetized by co-precipitating $\mathrm{Fe}^{2+}$ and $\mathrm{Fe}^{3+}$ to form a composite with magnetite particles of $\mathrm{Fe}_{3} \mathrm{O}_{4}$ (mPOS-PVA). Finally, the mPOS-PVA is activated with glutaraldehyde which acts as a chemical arm to link the enzyme molecules to the magnetic particles. This procedure has been previously and successfully used to immobilize antigens and lipase [16-19].

Some properties of the $\beta$-galactosidase immobilized on the mPOS-PVA acting on a synthetic substrate (o-nitrophenyl- $\beta$-Dgalactopyranoside) have been investigated and compared to those established for the native enzyme. Finally, the action of the 
immobilized lactase derivative was investigated on the hydrolysis of whole milk lactose.

\section{Materials}

$\beta$-Galactosidase from $K$. lactis was obtained from Novozymes (Bagsvaerd, Denmark). Polyvinyl alcohol, tetraethylorthosilicate, $\mathrm{FeCl}_{3}$ and $\mathrm{MgCl}_{2}$ were purchased from Fluka (Steinheim, Germany); $\mathrm{FeCl}_{2}$ and $o$-nitrophenol (ONP) from Riedel-de Haën (Steinheim, Germany); glutaraldehyde and 0 -nitrophenyl- $\beta$-Dgalactopyranoside (ONPG) from Sigma-Aldrich (Steinheim, Germany) and bovine serum albumin from Pierce (Rockford, United States). Low fat milk containing $4.72 \%(\mathrm{w} / \mathrm{v}$ ) of lactose, $\mathrm{pH} 7.15$, was acquired from the Pingo Doce (Minho, Portugal) supermarket. All other chemicals were of analytical grade or better.

\section{Experimental procedures}

\subsection{POS-PVA synthesis and magnetization}

POS-PVA beads were synthesized according to the procedure described by Barros et al. [16]. Briefly: $6 \mathrm{ml}$ of $2 \%(\mathrm{w} / \mathrm{v}$ ) polyvinyl alcohol, $5 \mathrm{ml}$ of ethanol and $5 \mathrm{ml}$ of tetraethylorthosilicate (TEOS) were mixed in a beaker. After heating up to $100^{\circ} \mathrm{C}$, under magnetic stirring, $100 \mu \mathrm{l}$ of concentrated $\mathrm{HCl}$ were added and the mixture incubated for an extra $50 \mathrm{~min}$. Subsequently, the solution was distributed into the wells of ELISA microplates ( $200 \mu \mathrm{l}$ per well) and allowed to solidify for ca. $48 \mathrm{~h}$ at $25^{\circ} \mathrm{C}$. The resulting beads were smashed using a mortar and pestle; the powder $(2 \mathrm{~g})$ suspended in deionized water $(100 \mathrm{ml})$ and $10 \mathrm{ml}$ of a solution containing $0.6 \mathrm{M} \mathrm{FeCl}_{2}$ and $1.1 \mathrm{M} \mathrm{FeCl}_{3}(1: 1)$ were added dropwise under magnetic stirring. Afterwards, the $\mathrm{pH}$ and temperature were adjusted, under overhead stirring, to 11.0 (using $33 \%, w / v, \mathrm{NH}_{4} \mathrm{OH}$ ) and $100{ }^{\circ} \mathrm{C}$, respectively, followed by incubation for $30 \mathrm{~min}$. The resulting magnetized particles were thoroughly washed with deionized water until pH 7.0 was reached [20] and collecting the magnetic particles by using a magnetic field (Ciba Corning; 6,000 Oe). The washed magnetic POS-PVA particles were dried at $50{ }^{\circ} \mathrm{C}$ overnight and finally sieved $(<100 \mu \mathrm{m})$.

\section{2. $\beta$-Galactosidase immobilization}

For activation of the support, $10 \mathrm{mg}$ of magnetized particles were incubated in $2.5 \%(\mathrm{v} / \mathrm{v})$ glutaraldehyde $(100 \mu \mathrm{l})$ in $900 \mu \mathrm{l}$ of $0.1 \mathrm{M} \mathrm{H}_{2} \mathrm{SO}_{4}$ under orbital stirring $\left(20 \mathrm{rpm}\right.$ ) for $2 \mathrm{~h}$ at $25^{\circ} \mathrm{C}$. Following this incubation period, the particles were washed five times with $20 \mathrm{mM}$ citrate-phosphate buffer, $\mathrm{pH} 6.5$, containing $4 \mathrm{mM}$ $\mathrm{MgCl}_{2}$. The glutaraldehyde-activated POS-PVA magnetized particles $(10 \mathrm{mg})$ were incubated with $1 \mathrm{ml} \beta$-galactosidase solution at different concentrations in the same buffer, for $18 \mathrm{~h}$ at $4{ }^{\circ} \mathrm{C}$ and $20 \mathrm{rpm}$. The enzymatic derivative thus produced was collected and washed 5 times with the aforementioned citrate-phosphate buffer. The immobilized enzyme was kept in the buffer at $4{ }^{\circ} \mathrm{C}$ until use and both the supernatant and washes were used for protein determination.

\section{3. $\beta$-Galactosidase activity and protein determinations}

The $\beta$-galactosidase activity assays were carried out using the artificial substrate ONPG $(20 \mathrm{mM})$ prepared in citrate-phosphate buffer enriched with $\mathrm{MgCl}_{2}$ since the hydrolysis is increased in the presence of the $\mathrm{Mg}^{2+}$ [21]. The product released in the assay, ONP, was determined via absorbance readings at $410 \mathrm{~nm}$. One $\beta$ galactosidase unit (U) was defined as the amount of enzyme which liberated one $\mu \mathrm{mol}$ of ONP per min per mg of protein at $25^{\circ} \mathrm{C}$. The protein concentration was determined according to the method described by Smith et al [22] using bovine serum albumin as standard. The amount of immobilized protein was calculated by the difference between the amount of protein offered to the support for immobilization and that found in the supernatant and the washing buffers.

\subsection{Determination of kinetic parameters}

The apparent Michaelis-Menten constant $\left(K_{\mathrm{m}}^{\mathrm{app}}\right)$ and the maximum velocity $\left(V_{\mathrm{m}}\right)$ were determined, using Lineweaver-Burke plot, for both soluble and immobilized enzyme derivative by assaying activity at different concentrations of ONPG (0.625-40 mM).

The activation energies $\left(E_{\mathrm{a}}\right)$ for both soluble and immobilized enzyme derivative were calculated according to the Arrhenius law (Eq. (1)) by measuring the activities at different temperatures below the optimal temperature

$\log$ (Activity) $=\log A-E_{\mathrm{a}} / 2303 \cdot R T$

where $E_{\mathrm{a}}$ is the activation energy of the reaction, $A$ the Arrhenius pre-exponential factor (or collision frequency), $T$ the absolute temperature and $R$ the universal gas constant. The values of $A$ and $E_{\mathrm{a}}$ were obtained via nonlinear regression of the linearized Arrhenius equation to the experimental data.

The catalytic efficiency of the immobilized enzyme was calculated as follows:

$$
\text { Catalytic efficiency }=\frac{\left(V_{\mathrm{m}} / K_{\mathrm{m}}^{\mathrm{app}}\right)_{\text {Immobilized }}}{\left(V_{\mathrm{m}} / K_{\mathrm{m}}^{\mathrm{app}}\right)_{\text {Soluble }}} \times 100
$$

\subsection{Effects of $\mathrm{pH}$ and temperature on the catalytic activity}

The effects of both $\mathrm{pH}$ and temperature on the activity of soluble and immobilized enzyme counterparts were investigated in the ranges 5.0-8.0 using $20 \mathrm{mM}$ citrate-phosphate buffer containing $4 \mathrm{mM} \mathrm{MgCl}$, and $30-70{ }^{\circ} \mathrm{C}$, respectively, using the aforementioned activity determination procedures.

\subsection{Thermal stability characterization and reuse of the enzymatic derivative}

Thermal stability of soluble and immobilized enzyme derivative was studied by incubating both enzymatic forms at $35^{\circ} \mathrm{C}$ for $24 \mathrm{~h}$. Appropriate aliquots of soluble and immobilized enzyme derivative were withdrawn at different time intervals and the activities determined after $30 \mathrm{~min}$ at $25^{\circ} \mathrm{C}$ (temperature equilibration) using the protocol described above.

The retention of activity of the immobilized enzyme derivative was evaluated by incubating the same immobilized preparation with ONPG for 20 times (between each successive use, the immobilized enzyme derivative was washed five times with $20 \mathrm{mM}$ citrate-phosphate buffer, $\mathrm{pH} 6.5$, containing $4 \mathrm{mM} \mathrm{MgCl}_{2}$ ). The ONP production was evaluated spectrophotometrically as described above.

\subsection{Lactose hydrolysis by the mPOS-PVA $\beta$-galactosidase derivative}

Ten eppendorfs each containing $1 \mathrm{ml}$ of low fat milk were incubated with the mPOS-PVA $\beta$-galactosidase $(10 \mathrm{mg})$ at $25^{\circ} \mathrm{C}$ under orbital stirring $(20 \mathrm{rpm})$. At predetermined time intervals, one eppendorf was withdrawn and the support immediately separated from the reaction medium by applying a magnetic field. Then, the reaction medium was heated at $100{ }^{\circ} \mathrm{C}$ for $10 \mathrm{~min}$ and filtered with a $0.2 \mathrm{~mm}$ syringe filter (to eliminate eventual magnetic particle not separated by the magnetic field). Following this, $100 \mu \mathrm{l}$ aliquots 
were withdrawn and assayed for lactose, galactose and glucose content by HPLC (Jasco AS-2057 Plus), employing a MetaCarb 87P $300 \mathrm{~mm} \times 7.8 \mathrm{~mm}$ column (Varian) at $80^{\circ} \mathrm{C}$, a refractive index detector (Jasco RI-2031 Plus) and a mobile phase Milli-Q water at a flow rate of $0.4 \mathrm{ml} \mathrm{min}^{-1}$ (Jasco PU-2080 Plus).

\subsection{Analysis of the stabilization of the quaternary structure of the enzyme}

To check the stabilization of the quaternary structure of the protein, the enzyme derivative was sequentially washed with a series of buffer solutions (three washouts were produced) and then with a series of urea $6 \mathrm{M}$ solutions (three washouts were equally produced). This treatment releases from the support any enzyme molecules and/or subunits that were not covalently bound to it, while it is unable to break the enzyme-support covalent attachment; all the bonds established between the enzyme and the support are indeed very stable secondary amino bonds, and stand still at $6 \mathrm{M}$ urea. In this way, any molecule that was not covalently attached to the support is released into the medium. Then, SDS-PAGE analysis of the supernatant together with all the washouts was performed, and the gel was stained with Coomassie Blue (when quantification of the enzyme molecules released into the supernatant was sought) and analyzed by densitometry.

\section{Results and discussion}

\subsection{MPOS-PVA characterization}

$\beta$-Galactosidase immobilization has been carried out on several supports, e.g., silica-alumina, thiopropyl-agarose, cellulose-gelatin, magnetic poly glycidylmethacrylate-methylmethacrylate (GMA-MMA) beads, glyoxyl and amino (MANAE) agarose and polyethyleneimine (PEI), alginate-gelatin fibers, celite and cellulose beads. These immobilization procedures involved physical adsorption, covalent coupling, cross-linking and entrapment. Fig. $1 \mathrm{~A}$ schematically displays the chemistry used in the support synthesis and immobilization procedure entertained in the present research effort, whereas Fig. 1B and 1C displays the scanning electron microscopy (SEM) analysis of non-magnetized and magnetized POS-PVA particles. The synthesized semi-interpenetrated network (first step: bead formation) combines the porous properties of glass (polysiloxane) with the vicinal hydroxyl groups of the organic polymer (polyvinyl alcohol). Afterwards, the beads are smashed to increase the immobilization surface (second step) and the particles are co-precipitated with $\mathrm{Fe}^{2+}$ and $\mathrm{Fe}^{3+}$ (third step) to provide them with magnetic properties in order to facilitate support recovery from the reaction medium. Finally, glutaraldehyde is attached to the polyvinyl alcohol vicinal hydroxyl groups under acid catalysis [23], and allowing the $\beta$-galactosidase immobilization by acting as a chemical spacer-arm. The linkage of the enzyme to the polyvinyl alcohol-glutaraldehyde is schematically represented in Fig. 1A as a Schiff's base, but glutaraldehyde may react in several ways [24]. The SEM images indicate rhombohedra particles and a slight increase in the size of the magnetized particles and a reduction on its sharpness that may be a consequence of the alteration of the electrical field following particle magnetization. The relationship between the amount of $\beta$-galactosidase offered to the mPOS-PVA particles and the retained protein, enzyme activity and the specific activity were studied. The fixed protein linearly increased with the amount of offered protein. A similar behaviour was observed for the amount of immobilized enzyme suggesting, as confirmed experimentally, that the retained specific activity remained constant for this range of offered enzyme concentrations. Based on the maintenance of the enzyme specific activity for different amounts of immobilized enzyme, it is possible to consider that mass transfer limitations are not a major concern. For the following experiments, an amount of offered enzyme of $0.19 \mathrm{mg} / \mathrm{ml}$ was used.

\subsection{Kinetic parameters}

The $K_{\mathrm{m}}$ and $K_{\mathrm{m}}^{\mathrm{app}}$ for the native and immobilized enzyme, respectively, were estimated as $2525 \pm 0.184 \mathrm{mM}$ and $2296 \pm 0.208 \mathrm{mM}$. This difference did not show to be statistically significant according to a $t$-Student test analysis $(F=1.200 ; p>0.05)$. This result suggests that the micro-events (partitioning, diffusional or mass transfer, conformational and steric effects) involving immobilized enzyme-substrate interaction and its microenvironment did not markedly disturb enzyme action. Higher $K_{\mathrm{m}}^{\mathrm{app}}$ values after $\beta$-galactosidase immobilization compared to those calculated for the soluble enzymes have been reported by other authors with

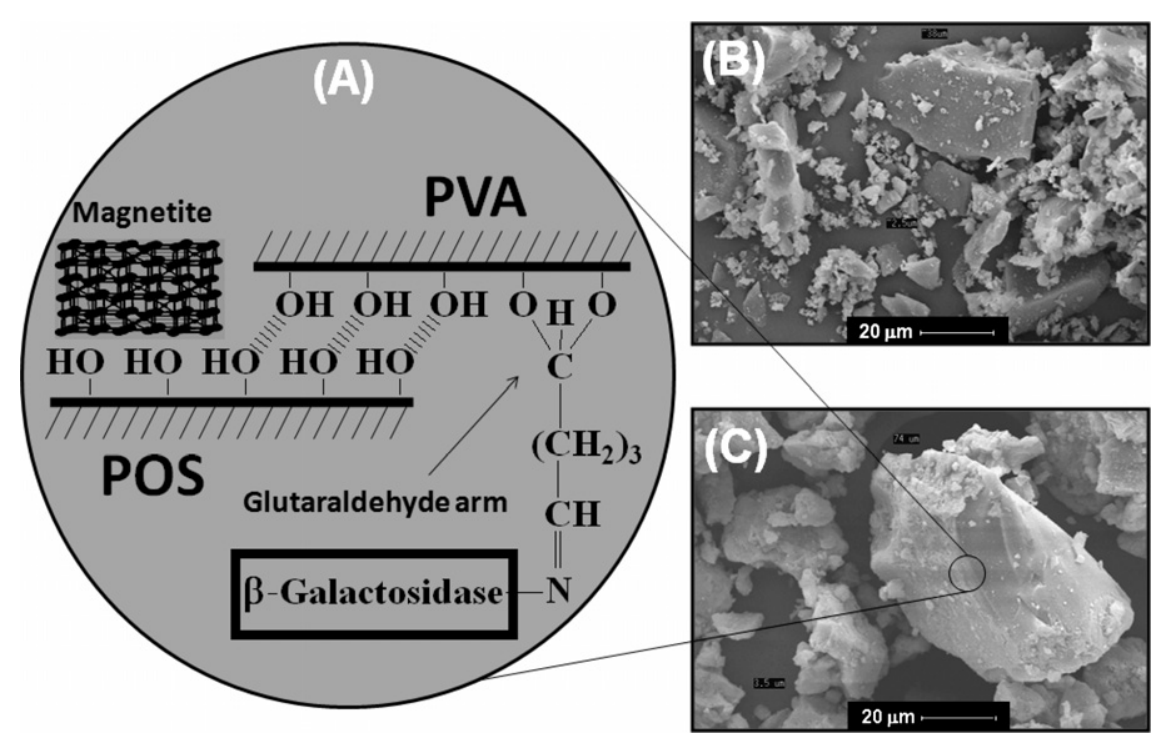

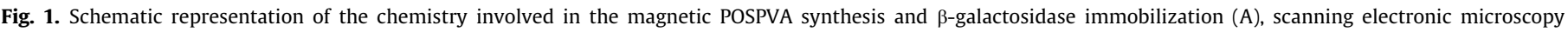
particles of non-magnetized (B) and magnetized (C) smashed beads of the semi-interpenetrated network of polysiloxane (POS) and polyvinyl alcohol (PVA). 
increases from 1.2-fold [14] up to 5.4-fold [6]. However, $\beta$-galactosidase from $K$. lactis immobilized on cellulose-gelatin showed a smaller value of $K_{\mathrm{m}}^{\mathrm{app}}(11.8 \mathrm{mM})$ than that estimated for the soluble enzyme (13.3 $\mathrm{mM}$ ) [9]. The fact that the immobilization of the enzyme on the present support does not alter the value of $K_{\mathrm{m}}^{\mathrm{app}}$ may be considered an important advantage when compared with most of the existing supports. Additionally, its magnetic characteristic provides easier recovery by a magnetic field. However, the catalytic efficiency of the immobilized enzyme was $12 \%$ compared to that found for the native enzyme. This reduced catalytic activity can be attributed to several factors, such as protein conformational changes induced by the support, steric hindrances and diffusional effects. These factors may operate simultaneously or separately, alternating the microenvironment around the bound enzyme [13].

The value of activation energy for the immobilized enzyme showed a marginal increase from $25.5 \pm 8.7$ for the soluble enzyme to $32.6 \pm 5.8 \mathrm{~kJ} \mathrm{~mol}^{-1}$. However, this difference was not significantly different according to a $t$-Student test analysis $(F=2.240$, $p>0.05$ ). Tu et al. [25] reported an increase of the activation energy value of the immobilized $\beta$-galactosidase from Cicer arietinum (gram chicken bean) on resin D202 from $41.6 \mathrm{~kJ} \mathrm{~mol}^{-1}$ (soluble enzyme) to $71.0 \mathrm{~kJ} \mathrm{~mol}^{-1}$. On the other hand, El-Masry et al. [26] registered a decrease of the Aspergillus oryzae $\beta$-galactosidase activation energy ( $\left.36.8 \mathrm{~kJ} \mathrm{~mol}^{-1}\right)$ after being immobilized on nylon membranes (25.1 $\left.\mathrm{kJ} \mathrm{mol}^{-1}\right)$.

\subsection{Effects of $\mathrm{pH}$ and temperature on the catalytic activity}

The optima $\mathrm{pH}$ and temperature values for both soluble and immobilized enzyme activities were found to be 6.5 (Fig. 2A) and $50{ }^{\circ} \mathrm{C}$ (Fig. 2B), respectively. The immobilized enzyme derivative was lightly more stable at higher $\mathrm{pH}$ : the soluble and the immobilized enzyme retained $15 \%$ and $25 \%$, respectively, of its initial activity at $\mathrm{pH}$ 8.0. This optimum $\mathrm{pH}$ is inside the range reported in the
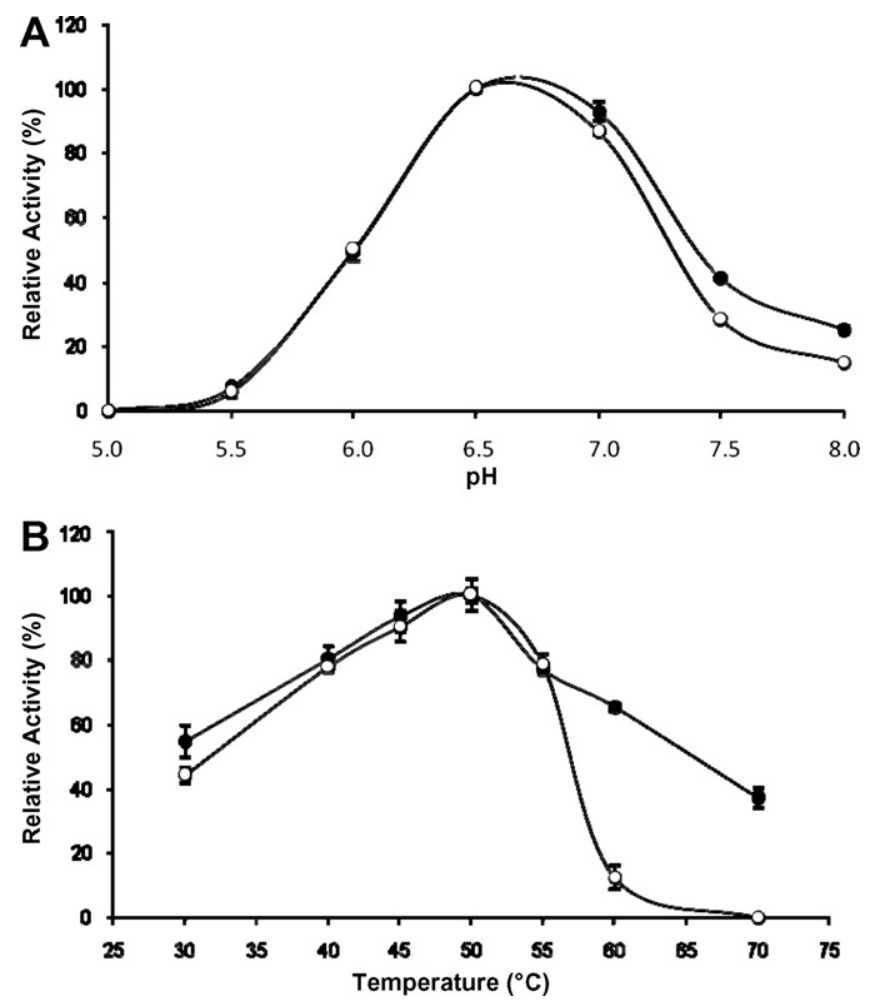

Fig. 2. Effect of the $\mathrm{pH}(\mathrm{A})$ and the temperature (B) on the activity of the soluble $(\mathrm{O})$ and the immobilized $\beta$-galactosidase $(\bullet)(N$ (number of replicates $)=3$ ). literature (6.0-7.0). Nevertheless, optima pH values of 4.5 [14] and 7.7 [27] have been cited for the A. oryzae $\beta$-galactosidase immobilized on fibers of alginate-gelatin and $K$. lactis $\beta$-galactosidase on graphite, respectively. The optimum temperature value for the immobilized derivative is equal to those reported in the literature for other immobilized $\beta$-galactosidase obtained from A. oryzae [14], $K$. lactis [27] and $K$. fragilis [10], and slightly lower $\left(55^{\circ} \mathrm{C}\right)$ than that found for the enzyme from Bacillus sp. [28]. However, different optimum temperature values have been reported for the $C$. arietinum $\beta$-galactosidase immobilized on modified resin D202 [25] and the E. coli enzyme on silanized porous glass modified [13], namely, $60^{\circ} \mathrm{C}$ and $35^{\circ} \mathrm{C}$, respectively. It is worthwhile to notice that at $70{ }^{\circ} \mathrm{C}$ the soluble enzyme lost all activity but the immobilized enzyme retained $37 \%$ of its initial activity. This thermal stability will be better demonstrated below.

\subsection{Measurement of thermal stability and reutilization of the enzymatic derivative}

The higher thermal stability of the $\beta$-galactosidase immobilized on mPOS-PVA compared to the soluble enzyme is depicted in Fig. $3 \mathrm{~A}$. The soluble enzyme lost of all activity after $10 \mathrm{~h}$ of incubation at $35^{\circ} \mathrm{C}$ whereas the immobilized one retained $47 \%$ of its initial activity at the end of one day of incubation. The increased stability observed in the immobilized enzyme should be attributed to a reduction in the protein structure mobility, due to anchorage to the support promoted by the covalent bonds and subsequent translation of the rigidity at each anchorage point to the whole enzyme structure, thus shielding it from damaging effects of the environment [29].

The immobilized $\beta$-galactosidase on mPOS-PVA was successively reutilized for 20 cycles at $25^{\circ} \mathrm{C}$ and at the end the enzymatic derivative retained approximately half of its initial activity (Fig. 3B). This decrease may be caused by the mass loss of the enzymatic derivative during the washing procedure. This performance of the
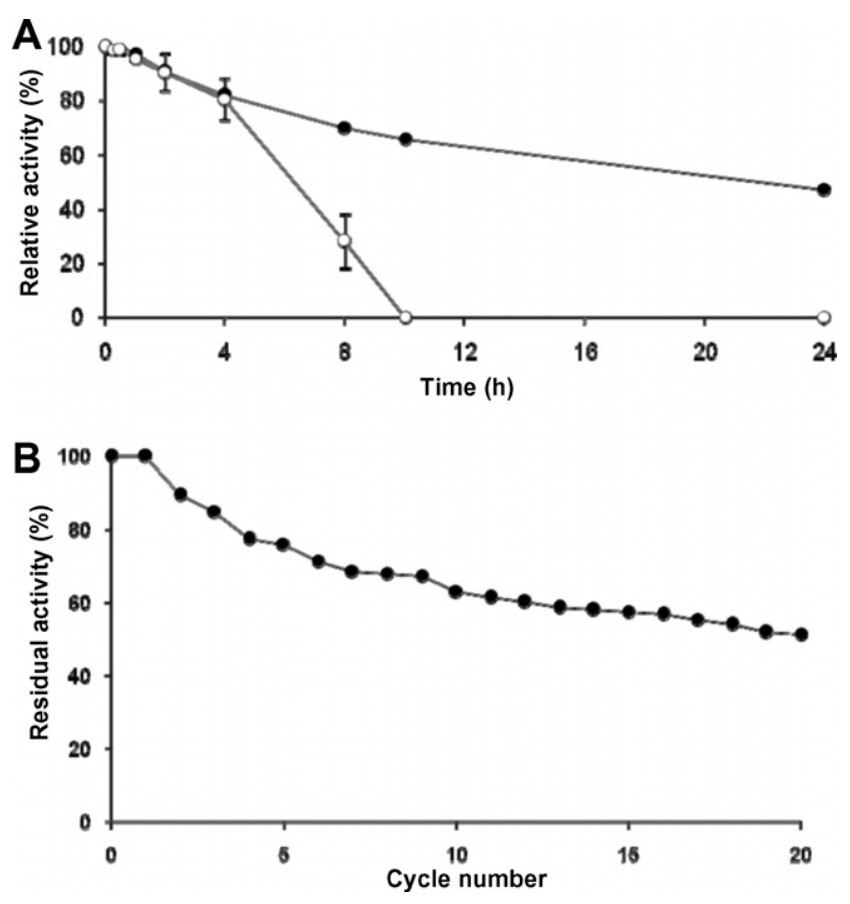

Fig. 3. Thermal stability of the soluble $(\bigcirc)$ and immobilized $(\bullet) \beta$-galactosidase at $35^{\circ} \mathrm{C}$, using ONPG as substrate Aliquots were withdrawn at the indicated time interval cooled to $25^{\circ} \mathrm{C}$ and assayed for residual activity. The initial activity at $25^{\circ} \mathrm{C}$ was taken as $100 \%$ activity $(\mathrm{A})(N=3)$. Effect of the number of reutilization cycles on the activity of $\beta$-galactosidase immobilized on mPOS-PVA (B) $(N=1)$. 


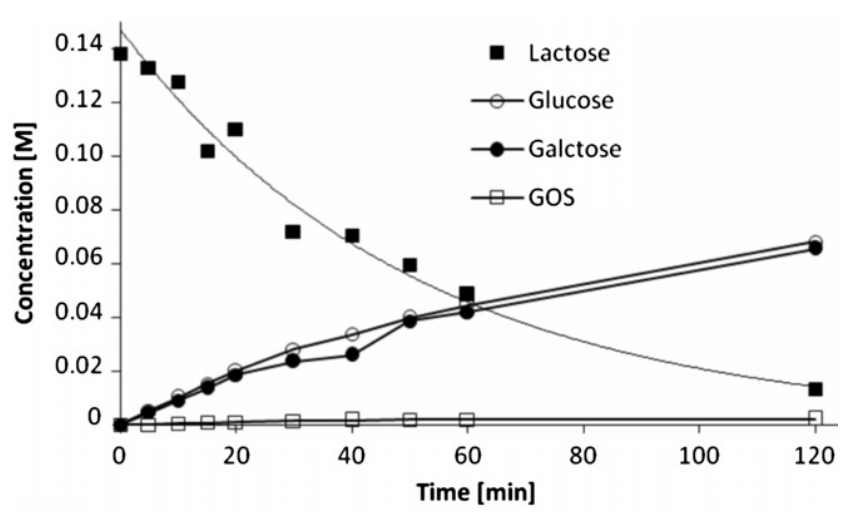

Fig. 4. Time course of the defatted milk lactose ( $\boldsymbol{\square})$ hydrolysis catalyzed by the $\beta$ galactosidase immobilized on mPOS-PVA and galactose $(\bullet)$, glucose $(\bigcirc)$ and galactooligosaccharides $(\square)$ release $(N=1)$.

mPOS-PVA $\beta$-galactosidase derivative would be an additional advantage besides that from its easy of separation from the reaction medium by a magnetic field. Bruno et al. [19] also used this support for the immobilization of Mucor miehei lipase and reported that after seven reutilization cycles the immobilized enzyme retained only $11.1 \%$ of the initial activity.

\subsection{Lactose hydrolysis by the mPOS-PVA $\beta$-galactosidase derivative}

Fig. 4 shows the action of the mPOS-PVA $\beta$-galactosidase on the lactose of low fat milk under batch reactor and at $25^{\circ} \mathrm{C}$. Almost all lactose (ca. 90\%) was hydrolyzed in galactose and glucose after 120 min of the immobilized enzyme action. It must be worthwhile to draw attention to the galactooligosaccharides formation. Similar results have been described by Giacomini et al. [30] and Roy and Gupta [10] using $K$. lactis $\beta$-galactosidase immobilized on CPCderivative and $K$. fragilis immobilized on cellulose beads acting on whey lactose, respectively. Zhou and Chen [6] working with $K$. lactis $\beta$-galactosidase immobilized onto graphite surface also reported galactooligosaccharides formation.

4.6. Study of the structural stabilization of the quaternary structure of the enzyme via multisubunit immobilization

Fig. 5 depicts the SDS-PAGE analysis of the supernatant, obtained after immobilizing the enzyme onto a mPOS-PVA, and of all enzyme derivative washouts produced (using both buffer and highly denaturating urea solution). From a simple inspection of
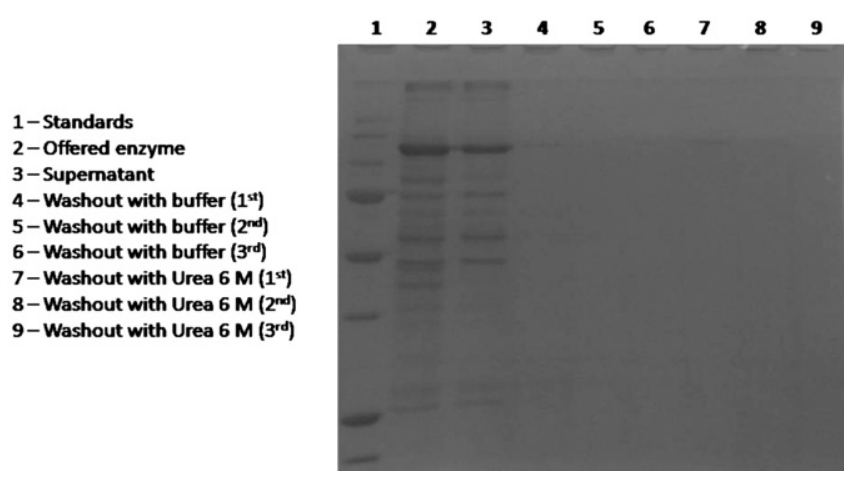

Fig. 5. Coomassie-stained electrophoretogram of offered soluble $\beta$-galactosidase and corresponding washouts following the enzyme immobilization protocol (lane 1: low molecular weight markers; lane 2: soluble enzyme offered to the support; lane 3: supernatant solution after immobilization timeframe; lanes 4-6: washout of the support with buffer; lanes 7-9: washout of the support with urea $6 \mathrm{M}$ ). the Coomassie-stained electrophoretogram produced, it is clear that the enzyme was indeed (irreversibly) covalently bound to the support, exerting a dramatic effect upon the structural stabilization of the enzyme. This can explain the high degree of retention of activity of the enzyme after the immobilization timeframe (see Fig. 4B), and can be correlated with a high degree of rigidification of the enzyme molecules following immobilization onto a mPOSPVA perhaps due to the lack of geometrical constraints (e.g., if the dimeric enzyme is a planar one, it will be virtually impossible not to get the two subunits interacting with a plane surface).

\section{Conclusions}

Magnetic polysiloxane-polyvinyl alcohol (mPOS-PVA) proved to be an attractive and efficient support for $\beta$-galactosidase immobilization due to the following arguments: the simplicity of the matrix synthesis and immobilization protocol; the easy removal of the reaction medium by simply applying a magnetic field on the reactor and the capability to catalyze the milk lactose hydrolysis into galactose and glucose and yielding galactooligosaccharides as well. The water insoluble synthesized enzymatic derivative acting on 0 -nitrophenyl- $\beta$-D-galactopyranoside displayed the same optima $\mathrm{pH}(6.5)$ and temperature $\left(50^{\circ} \mathrm{C}\right)$ of the native enzyme and similar apparent Michaelis-Menten constant (ca. $7 \mathrm{mM}$ on ONPG) and energy of activation (ca. $30 \mathrm{~kJ} \mathrm{~mol}^{-1}$ ) values. Furthermore, it retained about half of its initial activity after being reused 20 times at $25^{\circ} \mathrm{C}$ or being incubated once at $35^{\circ} \mathrm{C}$ for $24 \mathrm{~h}$, whereas the soluble enzyme counterpart lost all its activity when used under these conditions.

\section{Acknowledgements}

David F.M. Neri gratefully acknowledges support by the Programme Alßan, the European Union Programme of High Level Scholarships for Latin America (Scholarship No. E05D057787BR). Luiz B. Carvalho Jr. is recipient of a scholarship of the Brazilian National Research Council (CNPq).

\section{References}

[1] G. Bayramoglu, M. Yilmaz, M.Y. Arica, Food Chem. 84 (2004) 591

[2] V. Gekas, M. López-Leiva, Process Biochem. 20 (1985) 2.

[3] M. Kretchmer, Sci. Am. 227 (1972) 71.

[4] R. Gaur, H. Pant, R. Jain, S.K. Khare, Food Chem. 97 (2006) 426.

[5] A. Axelsson, G. Zachi, Appl. Biochem. Biotechnol. 24 (1990) 679.

[6] Q.Z.K. Zhou, X.D.J. Chen, Food Eng. 48 (2001) 69.

[7] B.C.C. Pessela, G. Dellamora-Ortiz, L. Betancor, M. Fuentes, J.M. Guisán, R. Fernandez-Lafuente, Enzyme Microb. Technol. 40 (2007) 310.

[8] K. Ovsejevi, V. Grazú, K. Cuadra, F. Batista-Viera, Enzyme Microb. Technol. 35 (2004) 203.

[9] Y. Numanoglu, S. Sungur, Process Biochem. 39 (2004) 703.

[10] I. Roy, M.N. Gupta, Process Biochem. 39 (2003) 325.

[11] B.C.C. Pessela, C. Mateo, M. Filho, A. Carrascosa, R. Fernández-Lafuente, J.M. Guisan, Enzyme Microb. Technol. 40 (2007) 242.

[12] M. Ladero, G. Ruiz, B.C.C. Pessela, A. Vian, A. Santos, F. Garcia-Ochoa, Biochem. Eng. J. 31 (2006) 14.

[13] G. Bayramoglu, Y. Tunali, M.Y. Arica, Catal. Commun. 8 (2007) 1094.

[14] A. Tanriseven, S. Dogan, Process Biochem. 38 (2007) 27.

[15] P.J. Halling, P. Dunnill, Enzyme Microb. Technol. 2 (1980) 2.

[16] A.L. Barros, A.M.P. Almeida, L.B. CarvalhoJr., W.M. Azevedo, Braz. J. Med. Biol. Res. 35 (2002) 449.

[17] R.A.L. Coêlho, G.A. Jaques, A.D. Barbosa, G. Velazquez, S.M.L. Montenegro, W.M. Azevedo, L.B. CarvalhoJr., Biotechnol. Lett. 24 (2002) 1705.

[18] L.M. Bruno, J.L. Lima-Filho, E.H.M. Melo, H.F. Castro, Appl. Biochem. Biotechnol. 113 (2004) 189.

[19] L.M. Bruno, J.S. Coelho, E.H.M. Melo, J.L. Lima-Filho, World J. Microbiol Biotechnol. 21 (2005) 189

[20] A.M.A. Carneiro-Leão, E.A. Oliveira, L.B. CarvalhoJr., Appl. Biochem. Biotechnol. 31 (1991) 53.

[21] S.H. Kim, K.P. Lim, H.S. Kim, J. Dairy Sci. 80 (1997) 2264.

[22] P.K. Smith, R.I. Khron, G.F. Hermanson, A.K. Mallia, F.H. Gartner, M.D. Provenzano, E.K. Fujimoto, N.M. Goeke, B.J. Olson, D.C. Klent, Anal. Biochem. 150 (1985) 76. 
[23] A.M. Araujo, M.T. Neves, W.M. Azevedo, G.G. Oliveira, D.L. Ferreira, R.A.L. Coêlho, E.A.P. Figueiredo, L.B. CarvalhoJr., Biotechnol. Tech. 11 (1997) 67.

[24] I. Migneault, C. Dartiguenave, M.J. Bertrand, K.C. Waldron, Biotechniques 37 (2004) 790.

[25] W. Tu, S. Sun, S. Nu, X. Li, Food Chem. 64 (1999) 495.

[26] M.M. El-Masry, A. De Maio, P.L. Martelli, R. Casadio, A.B. Moustafa, S. Rossi, D.G. Mita, J. Mol. Catal. B: Enzym. 16 (2001) 175.
[27] Q.Z.K. Zhou, X.D. Chen, Biochem. Eng. J. 9 (2001) 33.

[28] T.C. Cheng, K.J. Duan, D.C. Sheu, J. Chem. Technol. Biotechnol. 81 (2006) 233.

[29] E. Taqieddin, M. Amiji, Biomaterials 25 (2004) 1937.

[30] C. Giacomini, G. Irazoqui, F. Batista-Viera, B.M. Brena, J. Mol. Catal. B: Enzym. 11 (2001) 597. 